9 Goodman A, Goodman R. Population mean scores predict child mental disorder rates: validation SDQ prevalence estimators in Britain. J Child Psychol Psychiatry 2011; 52: 100-8.

10 Weare $\mathrm{K}$, Nind $\mathrm{M}$. Mental health promotion and problem prevention in schools: what does the evidence say? Health Promot Int 2011; 26 (suppl 1): i29-69.

11 Weare $\mathrm{K}$, Nind $\mathrm{M}$. Mental health promotion and problem prevention in schools: what does the evidence say? Health Promot Int 2011; 26 (suppl 1): i29-69

12 Stewart-Brown SL, Schrader-McMillan A. Parenting for mental health: what does the evidence say we need to do? Report of Workpackage 2 of the DataRev project. Health Promot Int 2011; 26 (suppl 1): i10-28.
13 Prinz RJ, Sanders MR, Shapiro CJ, Whitaker DJ, Lutzker JR. Population-based prevention of child maltreatment: The U.S. Triple P system population trial. Prev Sci 2009; 10: 1-12.

14 de Vibe $M$, Bjørndal A, Tipton E, Hammerstrøm $K$, Kowalski $K$. Mindfulness Based Stress Reduction (MBSR) for improving health, quality of life, and social functioning in adults. Campbell Syst Rev 2012: 3: 1-127.

15 Martine Asuero A, Moix Queraltó J, Pujol-Ribera E, Berenguera A, RodriguezBlanco $T$, Epstein RM. Effectiveness of a mindfulness education program in primary health care professionals: a pragmatic controlled trial. J Contin Educ Health Prof 2014; 34; 4-12.

16 Cattan $M$, White $M$, Bond J, Learmouth A. Preventing social isolation and Ioneliness among older people: a systematic review of health promotion interventions. Ageing Soc 2005; 25: 41-67.

\section{poems by doctors}

\title{
Shrink
}

Tricia Henry

She who would never leave the house without looking neat, who I never saw in her utility underwear,

was taken into care wearing a slip in the winter street.

she was shoeless and asking for me door-to-door.

Respite. Six-week evaluation. I packed for her for the short stay, rummaging through pants and bras. Clothes neatly folded, colour-coded, drawer-to-drawer. one small case was all. She asked me, "How long for?"

She stood diminished in a Home with a sea view. Shrivelled inches in height, fragile as glass. Her things were marked indelibly. We did it new every week; her clothes shrank in the wash.

Clothes that didn't shrink she didn't recognise as hers, the labels even less since they used her real name. Six weeks, then three months, she changed gears. I adjusted with her but didn't know who she became.

When she went to a locked ward she stopped asking for me. She let her mind contract. Time for me to clear her home of all her household icons. By degrees her character was bleached, she began to disappear.

I found hung up among her "special dresses" (all dry-cleaned and ready to wear) his trilby hat and sheepskin fur.

That smell that never leaves a coat, of smoke, of body, after-shave. Suddenly I, too, felt he was there.

And I pictured her recalling winters when he'd worn that coat, needing the texture of it to re-invent him, to keep her grounded and in the right dimension. I held its full length against me, warm, redolent.

Selected by Femi Oyebode.

Published in The Hippocrates Prize Anthology, Hippocrates Press, 2012. (c) Tricia Henry. Reprinted with permission. 